\title{
How Brazil's Agrarian Dynamics Shape Development Cooperation in Africa
}

\author{
Francesco Maria Pierri
}

Abstract This article shows how Brazil's history of agrarian dynamics shapes development cooperation. In particular, Brazil's dualistic agrarian structure frames policy discourse, and shapes development cooperation thinking and practice. Given Brazil's recent experience of rural poverty reduction, the article argues that a focus on 'family farming' is potentially the most productive form of engagement in development cooperation. This is illustrated through an analysis of Brazilian cooperation promoted by the Ministry of Agrarian Development (MDA), and in particular its More Food International Programme. While Brazilian family farms are very different to those found in Africa, there can be a productive exchange of experience, expertise and equipment. Key lessons from the Brazilian experience are the need for state backing and support, providing social security for the poor, offering financial support and technical expertise for family farming and the existence of effective social mobilisation by civil society.

\section{Introduction}

Brazil's agricultural cooperation with African countries has been under close scrutiny over recent years, as Brazil becomes an increasingly visible international development actor. Research on the topic is starting to emerge, both in countries with a longstanding tradition of African agrarian and international development studies (Cabral and Shankland 2013), but also within Brazil, as part of an effort to consolidate homebased African studies and fill gaps in knowledge of the African continent (Costa Leite forthcoming; Patriota and Pierri 2013). An interesting feature of these Brazil-based contributions is that their authors are not only researchers but also government officers, technocrats, representatives of civil society and small farmers' movements; all directly engaged in the domestic agricultural agenda and, occasionally, in international cooperation. This is encouraging because it establishes the basis for a pluralistic debate intermixing academic perspectives with practitioners' insights, which could help shape international cooperation paradigms and practices in line with the challenges ahead.

Often governmental narratives of development cooperation with Africa revolve around selflegitimating assumptions that cultural and ethnic ties render Brazil as a 'natural' partner for Africa. It is also commonly argued that agrarian similarities on the two sides of the Atlantic, eco-climatic characteristics and a huge small farm sector, make the transfer of technologies simple. Yet, alone, such ties and similarities will not result in reciprocal understanding or effective collaboration. Brazil's trajectories of agrarian development are different in many aspects from Africa's. If appropriate technologies and policies, respectful of home-grown strategies, are to be put in place through cooperation, both Brazilian and African actors involved need to know about these agrarian dynamics.

It has been argued that Brazilian cooperation lacks a clearly articulated policy for agricultural cooperation (Cabral and Shankland 2013). This view can be challenged, however. The proceedings document of the 2010 Brazil-Africa Dialogue (MRE 2010) contains the policies and approaches that form an 'official line' of cooperation, and that were discussed and formed consensually with African leaders and policymakers who attended the event. Besides, Brazil's guiding cooperation principles (of non-conditionality, non-interference and demand-driven cooperation), and their corresponding policies, form the basis of 
development cooperation. This is separate from the capacity to implement, adjust and commit the necessary resources for cooperation to take place effectively. The Brazilian government is currently dealing with this, and the broad contours are being shaped.

This article argues that, rather than not having a cooperation policy, Brazil is instead working with two different paradigms of agricultural development, with particular requirements in terms of sustainability, policies and agents. This article therefore focuses on the paradigms that frame agricultural cooperation; in particular the emphasis on a dualistic agrarian structure, and the understandings of 'agri-business' and 'family farming for food security'. The article explores the ideological underpinnings of these paradigms, each legitimising development cooperation in different ways. The article raises concerns about the consistency of such emphases, and explores the implications for international cooperation in agriculture in Africa.

The article argues that family farming is potentially the most productive area of cooperation towards the goal of sustainable development, given its social, economic and environmental basis. However, the article also challenges the idea that this simple assumption will lead inevitably to successful cooperation. It also questions whether there is an economic paradigm (state-led, market-led or a combination of the two) that is inherently suitable for family farming production structures. With respect to the African context, the article asks whether the Brazilian family farming context is relevant to the African smallholder. And finally, the article questions the extent to which peasant organisations should take part in the transfer of Brazilian cooperation experiences to Africa. These interrelated topics, all grounded in a political economy analysis, in turn call for a more in-depth intellectual debate on how histories of agrarian dynamics shape development cooperation.

\section{Three contextual factors shaping Brazil-Africa cooperation}

Brazil-Africa cooperation should be assessed within the wider context of three major factors that have shaped Brazil's development trajectory since the election of President Lula in 2003 (Patriota and Pierri 2013). These factors are: macroeconomic stability; unprecedented reduction in inequality, poverty and food insecurity; and a realignment of focus in foreign policy with the view of expanding commercial ties worldwide and strengthening Brazil's profile in the international scene.

Firstly, Brazil attained macroeconomic stability through a growth pattern centred on the expansion of internal markets and massive public investments. It paid off its external debt and was relatively cushioned from international economic turmoil. Stability was achieved throughout a decade marked by a severe international food crisis (2007/08), the second deepest world recession of monopoly capitalism, and also by growing Chinese demand for commodities. Brazil took advantage of the commodity boom windfall, but at the same time maintained orthodox macroeconomic policies. However, while adherence to neoliberal tenets was steadily abandoned, beginning from the end of President Lula's first term, a drive reinforced under President Rousseff's ongoing administration, commodity revenues have remained the sole surplus source for the country's balance of payments.

Secondly, growth was coupled with a major reduction of inequality, poverty and food insecurity. The Gini index of income concentration, declined from 0.60 in 1997 to 0.54 in 2009. Between 2003 and 2009, 29 million people entered the 'new middle class', ' while 15 million jobs were created (Neri 2010). In the same period, poverty decreased by 45.5 per cent, with more than 20 million people stepping above the poverty line. Also, child malnutrition (0-5 years) dropped from 13 to 7 per cent between 1996 and 2006 (CONSEA et al. 2009).

Food security was reached with the implementation of the 'Zero Hunger' strategy which combines extending access to food for the low-income population through conditional cash transfers (the Bolsa Família programme), public utilities, school meals programmes, along with the improvement in the minimum wage. This has resulted in the strengthening of family farming, the country's largest agricultural sector. ${ }^{2}$ According to the 2006 agricultural census there are 4,367,902 agricultural establishments based on family farming, representing 84 per cent of the total. They cover an area of 80.3 million hectares (24 per cent of total agricultural area) and employ 74 per cent of the agricultural 
workforce (12.3 million people). The average area of these family farms is 18.37 hectares.

Almost 4.8 million people from rural areas emerged from poverty (corresponding to 869,000 family farms). This movement was pushed by an upward rural income trajectory marked by increases in the rent obtained by agricultural and non-agricultural activities (18 and 30 per cent respectively) (Del Grossi 2010), and not just social policies. Public policies for this sector were financed by massive public spending and reached out to a vast number of small farmers nationwide. Support across the entire value chains delivered outstanding results. Today, the more capitalised and organised family farmers produce 70 per cent of national food requirements and around 10 per cent of the value generated by the whole agri-business chain (DIEESE et al. 2011). Their productivity per hectare is currently 89 per cent higher than that of large-scale monoculture (MDA 2009).

Yet, continuities also need to be stressed. While more than 600,000 families received their title to land in this period, the agrarian property structure of the country remains highly concentrated. The Gini index of land distribution in 2006 was 0,856 , a figure practically unchanged since 1975. Also, reliance on commodities has restated the political weight of traditional dominant groups and socioeconomic structures. Despite some progress, 16 million people continue to live in extreme poverty, almost half of them in rural areas.

These socioeconomic changes ran in parallel with a substantial foreign policy shift, driven by the aim of expanding commercial ties worldwide and the strengthening of multilateralism and the weight of the country in multilateral institutions. This was epitomised by the abandonment of the Free Trade Area of the Americas' (FTAA) negotiations in November 2003, pushed by mounting criticism from civil society, especially from rural movements. The new pillars for external relations were the prioritisation of the South American integration project, the launch of a South Atlantic dialogue with African countries and the setting of pluri-lateral mechanisms among 'emerging countries', such as IBSA and BRICS, the latter being increasingly used as platforms for positioning in the multilateral arena.
The result has been Brazil's shift from 'recipient' status in international cooperation toward increasing engagement in technical cooperation with developing countries. This exposure reached political momentum at the onset of the international food and economic crisis of 2007-08, when Brazil found itself endowed with diplomatic, technological and policy credentials that turned it into a prominent actor for policy dialogue and technical cooperation on agricultural and food security matters. The crisis also triggered a widening disenchantment with the neoliberal recipe, something symbolised by the stalling of the World Trade Organization (WTO) Doha Round, mainly because of disagreement over the agricultural chapter. This also bestowed on Brazil an international acknowledgement of having successfully built a food security system based upon a strategy of strong state intervention, domestic support, credit and other policies aiming to strengthen internal markets. These outcomes were particularly appealing for the other side of the Atlantic at a moment in which the principal agenda of the African Union was the implementation of the Comprehensive Africa Agriculture Development Programme (CAADP), launched in 2003. This permitted Brazil to launch an ambitious framework for cooperation with African countries. In May 2010, President Lula launched the Brazil-Africa Dialogue on Food Security, the Fight Against Hunger and Rural Development that enjoyed wide consensus and ultimately achieved sufficient alignment for the election of the leading mentor of its food security strategy as the new Director General of the FAO, José Graziano da Silva.

\section{Dualism as the modus operandi of Brazilian agricultural cooperation}

The legitimisation of family farming as a policy domain overseen by the Ministry of Agrarian Development (MDA) in the first decade of the Workers' Party government was instrumental in underpinning the basis of a dual agricultural strategy. At the same time, positive outcomes in food production and food security attained by this sector were important in consolidating the strategy.

In Brazil's complex urban-industrial society, a substantial part of the capacity of new narratives to emerge and persist in the development discourse is their acceptance by the middle 
urban classes as the main recipient of mass media-shaped messages. The promotion of the family farming narrative among the middle class was a deliberate cultural operation unleashed in President Lula's first mandate by the left-wing arm of the Workers' Party, which highly influenced the MDA. Modern web-based technologies, own-managed TV channels and radio stations, and the holding of national and regional fairs in the main capital cities, where products of this sector were shown and cultural and artistic events took place, were all used to promote this new policy thrust. ${ }^{3}$

However reductionist this operation might have been, it was successful in conveying the message. Brazilians are becoming increasingly aware that what they consume is mainly produced by these farmers and that the country has a positive trade balance, not only because of agri-business exports, but also because Brazil does not need to import many foodstuffs. As a consequence, the agricultural tradition of large-scale property, monoculture and wage labour for commodity export, which had long nurtured the dominant discourse, is now contending not only with a new public policy narrative of 'family farming for food security', but also the attention of the middle class. This has been a major accomplishment in a relatively short timeframe.

Beyond narratives, however, Brazil has a solid intellectual tradition of agrarian studies that have analysed in-depth the relations of production between family farming and capitalist agriculture, giving us a good understanding of the complex nature of the country's agrarian structure. Economic and sociological research has delivered a huge amount of analysis on agrarian modernisation, dualism and family farming since the beginning of the re-democratisation process in late 1979. These studies have depicted patterns of land reforms, socioeconomic differentiation, agro-industrial integration, contract farming, territorial development and settlement and gender relations, amongst other issues. ${ }^{4}$ Above all, these studies have agreed upon the existence of an 'agrarian question' in presentday Brazil, made of old and new aspects. An old agrarian question persists as long as the agrarian structure remains concentrated, and struggles for land continue to be waged by landless or landshort poor peasants. Yet the resolution of the agrarian question in terms of ending land concentration is no longer seen as a precondition for securing national food supply and attaining development, at least in the reductionist perspective of development as 'growth'. Nevertheless, the debate on which development model to adopt continues to be raised by agrarian reform debates grounded in issues of sustainable development (loss of biodiversity, competing uses of land, water and other natural resources, etc.), land rights claimed by ethnic minorities (the indigenous people), rural communities of Afrodescendants (quilombolas), and labour conditions in large farms, including the persistence of forms of bonded labour, especially in Amazonia.

Agrarian dualism is thus the main channel through which agricultural policies are thought about and delivered in Brazil. The MDA supports the family farm sector, while the Ministry of Agriculture, Livestock and Food Supply (MAPA) supports the agri-business sector. The domestic development of policies and technologies for the two sectors has also shaped a bimodal capacity and modus operandi for cooperation with developing countries.

While Brazil's dominant discourse at the level of the UN Rome-based agencies (the Food and Agriculture Organization (FAO), the International Fund for Agricultural Development (IFAD) and the World Food Programme (WFP)) and in plurilateral initiatives such as the G20 revolves around the 'family farming for food security' motto, the country's technological and research capacity for large-scale capitalist agriculture is made available whenever requested in bilateral or trilateral arrangements, whether for biofuels or food crop production, particularly in Africa.

Dualism in the cooperation platform thus reflects Brazil's agrarian political economy and, possibly increasingly, African demands too, as African governments look to strengthen large and medium-scale commercial agriculture alongside smallholder production systems. In both Brazil and (some parts of) Africa, agrarian dualism is an important feature of the agrarian political economy and will be resolved as part of class struggles, on the one hand, and the capacity of the political agents of these struggles to contest the state, its policies and budgets, on the other.

In Latin America, agricultural policies mirror agrarian trajectories which are dominated by the 
transformation of historically large holdings (latifundios) into large-scale agri-businesses. Military confrontation under authoritarian states often crushed agrarian development trajectories based on peasant modes of production, while neoliberal policy experiments through the 1980s and 90 s continued this work in their export-led strategies. Progressive and leftist Latin American governments of the twenty-first century are beginning to modify these trajectories, albeit with varying political commitment. Overall though, accommodation of the two models is the most dominant approach.

Brazil can be taken as an example of a reformist accommodation approach, as family farming has been prioritised in public policies, institutions and budgets more firmly than in other Latin American countries. But even where the most radical changes occurred in the agrarian structure and/or in the political economy of either continent - Bolivia and Zimbabwe, for example, where, respectively, an indigenousbased and socialist-inspired movement attained political power and a vast land occupation movement produced a situation that delivered the 'first radical shift in agrarian property rights in the post-Cold War world' (Moyo and Yeros 2005) - dualism was maintained, albeit under a new ideological and material basis. The question then is not the existence of dualism per se but rather its level of asymmetry.

\section{Family farming and the developmental state}

As one element of this dualism, this section focuses on the family farming paradigm, where in Brazil a state-led strategy is central. The issue of the adaptability of the Brazilian experience to Africa through technical cooperation is raised in particular.

Capable bureaucracies working in solid institutions and agencies are key features of a developmental state (Chang 2011; Evans 2011). Rural perspectives add that addressing the agrarian question 'through state-facilitated redistributive land reforms, building of the productive and social capabilities of peasants, and interventions that support agro-industrial growth and diversification [have been] critical to generating developmental success' (Moyo 2011: 1).

Such developmental state perspectives have been influential in shaping both Brazil's trajectory of agrarian development, and family farming policies in particular, and thus its platform for international cooperation. While recognising that markets and agricultural productivity matter, Brazil's family farming policy framework has been based on the premise that agrarian development with food security and social inclusion is essentially a state-led process for the delivery of the right public policies and regulation. Non-regulated markets lead to concentration of natural resources, means of production and knowledge, undermining agrarian development and food security. Such a premise became clearer when, at the beginning of the Lula government, market agents were found unable and/or unwilling to assume the inherent costs of delivering pro-poor agricultural policies and public goods, and to respond to the ambitions of a government that had peasant movements among its main constituencies.

Credit for small and under-resourced farmers is a case in point. The private banking system could not afford lending at low interest rates or cover insurance schemes for hundreds of thousands of underdeveloped small farms. Publicly subsidised credit and other services hence emerged as a pragmatic and urgent alternative. Over ten years, the state has developed a range of policies to support the family farming sector, under the umbrella of the National Programme for Strengthening Family Farming (PRONAF). These policies include: providing credit and insurance schemes tailored to family farmers, setting of minimum prices, establishment of public procurement schemes, investment in research and technology, spending on technical assistance and rural extension and land reform.

Despite the launch of PRONAF's credit programme in 1995, it was only in 2003, with stronger political commitment, that public funds for agricultural credit started to rise on a considerable scale. ${ }^{5}$

How then can such experience be translated into African settings? What are the limits and opportunities of transfer through a development cooperation framework? This section outlines three key issues.

\subsection{Financial capacity}

The question for African countries then is how to finance agricultural and food security strategies based upon a strong-state paradigm that 
encompasses the institutionalisation and execution of an array of public policies. It hinges on the fiscal capacity to pursue a trajectory that requires financial sustainability. Indeed, can an agricultural policy apparatus, which was built over a long period in Brazil as a central component for rural development, be transferred into the African context, and if so, to what extent and with what timeframe?

Oil or other mineral-rich African countries may set apart the necessary resources to finance such efforts once the question of political commitment is resolved. Countries not endowed with similar resources are compelled to rely on the same accumulation of competing agrarian strategies that have framed the domestic agricultural policy of development partners such as Brazil.

Resources raised through international cooperation are usually earmarked to finance the execution of development projects which are limited in scale and spatial coverage. This is a central issue in the design of cooperation projects because it involves crucial choices over which policies and which scale of operation need to be prioritised.

Trilateral and multilateral cooperation can be used to scale up resources and coordinate cooperation efforts in resource-constrained African countries. This type of coordination has been not been adequately achieved yet in existing informal multilateral fora such as IBSA (a group involving India, Brazil and South Africa) or the BRICS (Brazil, Russia, India, China and South Africa). IBSA has undertaken a series of smallscale cooperation projects in several African countries (Sierra Leone, Burundi, Cape Verde and Guinea Bissau), including some in the agricultural domain, through a UNDP-managed IBSA Fund. The BRICS Action Plan on Agricultural Cooperation for the period 2012-16 is mainly a platform for sharing technologies and know-how among member countries, while attempts to build up mechanisms for coordination at the FAO are being discussed, alongside the creation of a BRICS Development Bank

\subsection{The role of social mobilisation in public policy}

Beyond finance, a major challenge for African countries concerns reproducing the state-society dynamics that characterise Brazil's agricultural governance and that has played a central role in the creation and consolidation of the family farming framework.

By 2003, the pro-family farming Brazilian discourse in multilateral fora argued, almost as a leitmotif, that agrarian development requires specific public agencies, since traditional institutions (the agriculture ministries) were mostly influenced by large-scale agriculture groups used to gain the lion's share of funding. A substantial part of this message was premised on a vibrant social mobilisation process that called for the creation of agricultural developmental institutions and policies to support family farming and agrarian reform and the recognition of social movements as policymaking actors. Such mobilisation unfolded as part of a process of re-democratisation of the political system.

The agricultural modernisation led by the military regime, from 1964 to 1984, was driven by a deliberate political commitment to privilege the transformation of existing latifundios into a largescale, capital-intensive, commodity-producing sector to the detriment of reformist and redistributive alternatives voiced by peasant, landless and waged labourers. The end of open military repression created momentum to open up the debate on land reform, public policies and social security rights. This resulted in the creation of a Land Reform Plan in 1985, PRONAF in 1995 in tandem with the creation of the Ministry for Agrarian Reform, in the midst of nationwide concern about violent repression of rural conflicts. The Ministry of Agrarian Development was eventually established in 1999 to oversee family farming policy and the land reform process. ${ }^{6} \mathrm{In}$ 2003, building on the experience of municipal councils for rural development and a previous national body, the National Council for Sustainable Rural Development (CONDRAF) was created, a body coordinated by the MDA and composed by government and civil society members. In 2008, CONDRAF launched the first National Conference on Sustainable Rural Development and Solidarity, established on the basis of a bottom-up participatory process of conferences starting at municipal level. This forum institutionalised the perspective that rural development directives in Brazil were to be formulated through a nationwide process of social dialogue and consensus. In 2010, a Rural Development Plan was approved by CONDRAF (Plano de Desenvolvimento do Brasil Rural). 
Despite these achievements, rural movements in Brazil maintain their classical forms of demonstration and are able to organise their claims on almost any kind of agricultural or rural policy issue.

In the African context, despite the fact that small farms make up the bulk of agricultural production structures, the same political and cultural constraints that had long hampered (and in some cases continue to hamper) the building of government-peasant alliances in Brazil, have been operating. This was the case especially under structural adjustment programmes that dismantled the postindependence state-building advancements and privileged export-oriented capital-intensive agricultural sectors, sometimes under the guise of post-apartheid capitalist 'indigenisation' strategies as in Southern Africa.

Brazil should not hide behind the principle that it is not its business to deal with such sensitive domestic realms. The issue of the social alignment necessary to establish sustainable support across the entire value chain is a very important aspect of its agricultural developmental trajectory and one that cannot be omitted in the cooperation platform. This is particularly relevant when one considers that interventionism, especially when the beneficiaries are small farmers, can lead to dangerous top-down approaches no matter how pro-poor they claim to be.

Recent peasant outcries in Mozambique, for example, over projects that were criticised for lack of transparency and consultation, are sound reminders of how legitimate these concerns are (Chichava et al. 2013; UNAC 2012). Peasants should be seen not just as 'beneficiaries' but also as development agents across the agricultural value chain.

Brazil's credit policy to family farmers can be used to illustrate this point. Credit insolvency for family farmers has never passed 4.1 per cent since the launch of PRONAF. This is a rate considered manageable by the Brazilian treasury. Given that credit is, in most cases, provided with no collateral requirement, what kind of measures guarantee such positive achievement?? The answer lies in two interrelated societal factors. Firstly, credit cannot be accessed without having been registered in a national cadastre in which union- based agencies are credited by the government to issue the titles of 'family farmer'. Secondly, the title-holding farmer cannot ask for credit from the bank without presenting an agricultural project formulated with the assistance of extension agents, and a good portion of these also come from the same union-based agencies credited by the government to take part in the national technical assistance and rural extension system. This is quite an accountable public system made possible through what have been labelled 'social technologies' in Brazil.

Such social technologies therefore must be included in the Brazilian cooperation platform. Yet the necessary condition is that not only government agencies, but also unions and other civil society organisations need to participate actively in cooperation activities. This calls for political commitment on the part of both African and Brazilian governments.

There are some isolated examples of civil society involvement as providers of Brazil's technical cooperation, such as a project on native seeds management in South Africa and Mozambique (Cabral and Shankland 2013). But up to now, few such initiatives have been developed.

\subsection{African peasants and Brazilian family farmers}

How relevant, then, is Brazil's social mobilisation experience to the needs of African peasants? Are the struggles of Brazilian family farmers similar to those of the average African farmer?

As observed by Wiggins (2009), the vast majority of African farms (33 million or 80 per cent of the total) are small plots with an average of 1.6 hectares. Jayne et al. (2005) add that in Southern and Eastern Africa quite often the first quartile of small farms are two or more hectares, while the remaining 75 per cent are less than one hectare.

The majority of peasant farmers in Africa (land scarce, undercapitalised, semi-proletarianised farmers, often located in low fertile soils and stressed eco-climatic settings) are comparable to poor family farmers in Brazil, who provide sizeable contributions to the agricultural and food economy. However, such poorer farmers have benefited relatively less from family farming policies, which have tended to perform more successfully with the relatively better off family farmers. 
This should be a matter of reflection as part of the Brazil-Africa dialogue, if this is to have an effective impact on poverty. One proposition is to consider the potential of adopting a twin-track approach combining Brazil's social protection and agricultural policies, as is being attempted by Brazil's latest poverty eradication programme - 'Brazil without extreme poverty' (Brasil sem miséria). ${ }^{8}$

While an adaptation of such approaches to the African context raises the same questions of financial conditions and institutional arrangements mentioned above, an important field of cooperation could be worked out of the public and social technologies necessary to create and maintain such social protection and productive inclusion networks.

\section{The case of More Food International}

How then are these three principles being played out in practice? This section examines More Food International, which has thus far been the MDA's main instrument of cooperation with African countries.

Drawing on Brazil's own More Food programme, it focuses on improving farmers' access to equipment, machinery and agricultural technologies. This cooperation programme, originally set up as More Food Africa but renamed as More Food International in 2012, consists of a concessional credit scheme designed to support access by African family farmers to equipment, machinery and technologies required to increase productivity (Patriota and Pierri 2013; Costa Leite forthcoming).

The programme is expected to contribute to increased productivity but also address other goals, such as reducing drudgery and strengthening financial and environmental sustainability. The challenge is, as remarked by Amanor (2013), to avoid subsidised technologies ending up benefiting well-off farmers. Despite such risk, the programme is targeted at small and medium farmers, and the supplied equipment and machinery, as well as the financial conditions attached to the loan, have been designed for these types of farmers.

There have been concerns that the equipment provided - assumed to be just tractors - under the programme may not be economically viable to smallholder farmers in Africa (Amanor 2013). Such concerns, however, fail to note that tractors are not the only inputs made available by the programme or the only one demanded by the African partner. Instead, a wide array of inputs is available from irrigation schemes to motocultivators, from tractors to seeders, from storage facilities to dairy equipment. Where tractors are demanded, the offer is of tractors with power ranges of $15-75 \mathrm{hp}$, to ensure that small tractors for small farms are the option. Furthermore, cooperative schemes of tractor ownership and/or use and management are being privileged by both the Brazilian and African governments in order to incentivise the association of producers and provide economies of scale in the consumption of energy and other operational costs. While small plots are the dominant features in the African context, a substantial proportion of them are to be found in communal areas in proximity or even contiguity to each other, so that they present favourable conditions for this strategy to be deployed. ${ }^{9}$

Nevertheless, a refusal of credit by the government of Brazil on the grounds that the agricultural project for which the credit is asked for is not targeted to small farmers would be a violation of Brazil's principles of non-conditionality, noninterference and demand-driven cooperation. This is a reminder of the complexity and delicacy of having an 'official line' that encompasses both modalities and scope of cooperation in a South-South cooperation context.

So far three countries (Ghana, Zimbabwe and Mozambique) have been given credit and signed a technical cooperation project (TCP), while two others signed the TCP (Kenya and Senegal) and are negotiating the credit. Shipping of machinery and equipment will begin in 2013 after concluding the export guarantees procedures with the exporters in 2012. Depending on the TCPs signed, a number of Brazilian bodies are involved in cooperation activities, among them the Brazilian Agricultural Research Corporation (Embrapa) and several technical assistance and rural extension agencies. The setting up of a TCP is an exercise that involves negotiating a list of machinery and equipment that best fit the kind of agricultural activities and production goals envisaged by the African government, as well as being matched to the soil and other physical contexts in which the activities will occur. 
The code of conduct of the Brazilian government adheres to the three principles mentioned above, within the frame of a line of credit institutionally designed to support family farming-based agricultural development projects. So far this has been a very collaborative exercise that has led to reciprocal understanding and the improvement of methodologies of discussion and negotiation.

\section{Conclusion}

Brazil's cooperation with African countries on agricultural and food security has captured increasing attention at home and abroad since it was launched as a central component of foreign policy under President Lula's administration. Research and debate on the theme is now starting to build up, but further in-depth analysis is still needed. Emerging research has raised issues about Brazil's strategy (dualism and the policy of 'no-policy'), its relatively early stages of development (lack of a coherent and effective structure of governance) and the degree of novelty vis-à-vis traditional North-South cooperation. Additionally, a very interesting debate on the role of civil society in cooperation

\section{Notes}

1 Rising from the two lowest income quintiles (D and $\mathrm{E}$ ) to the third or $\mathrm{C}$ class, according to the statistical categories used by the Brazilian Institute of Geography and Statistics (IBGE).

2 Recent rural income-based analyses show that family farms can be grouped into four large segments: 'dynamic' $(88,000)$; 'in transition' (600,000 farm units); 'poor with agricultural revenues', 'poor without agricultural revenues' (2.2 million and 700,000); and 'pluri-activities' $(800,000)$.

3 The most important event is the 'Feira Nacional da Agricultura Familiar e Reforma Agrária - Brasil Rural Contemporâneo' (National Fair of Family Farming and Agrarian Reform - Contemporary Rural Brazil), held for the seventh time in 2012.

4 Classic works are: Abramovay (1998), da Silva (1981), Souza (1986), Gorender (1994). For a review, see Wanderley (2011).

5 Credit made available rose 400 per cent in the 2003-13 period, from $\mathrm{R} \$ 3,9$ to 18 billion.

6 Particularly moving was the massacre of Eldorado dos Carajás in the Amazonian state is under way which promises to deliver valuable contributions.

This article has argued that dualism will be a feature of Brazilian agricultural cooperation as long the agrarian political economy of Brazil and demand from Africa continues to reflect this dualism. However, the article has emphasised the need to scale up cooperation focused on family farming. It has warned that the current agenda risks relying upon simplistic assumptions (of affinities and similar conditions) that will not be conducive to positive outcomes. Along with discussing the adequacy of transferring and adapting Brazilian technologies and know-how in African countries, exchanging knowledge on African trajectories of agrarian development with Brazilian cooperation agents is becoming an imperative. Several features of agricultural development are recurrent, as the international comparative history illustrates. Notably, the need for a developmental state to work with the support of sufficient financial resources and public policies cannot be omitted in the cooperation discourse.

of Pará, on 17 April 1996, where 19 landless people were shot dead while protesting for government delay in expropriating several unproductive large farms.

7 Collateral is not required for credit operations worth less than $\mathrm{R} \$ 30,000$. Average credit provided to finance variable costs is $\mathrm{R} \$ 15,000$ and average credit for investment is $\mathrm{R} \$ 45,000$. Source: interview with João Guadagnin, Coordinator of Agriculture Production's Financing and Protection Department, Ministry of Agrarian Development.

8 BSM is designed around three pillars (income guarantees, access to public services and productive inclusion) and aims at improving welfare and increasing income for beneficiaries targeted through a tool called 'active search' (busca ativa) that brings the poor into a single public registry (Cadastro Único), permanently monitoring their access to the policies and services provided under the pillars.

9 In all the field visits that the author made in Zimbabwe to accompany the programme, all mechanisation schemes were conceived on an associational basis. 


\section{References}

Abramovay, R. (1998) Paradigmas do capitalismo agrário em questão, São Paulo/Campinas: Hucitec/Editora da UNICAMP

Amanor, K.S. (2013) South-South Cooperation in Context: Perspectives from Africa, FAC Working Paper 054, Brighton: Future Agricultures Consortium

Cabral, L. and Shankland, A. (2013) Narratives of Brazil-Africa Cooperation for Agricultural Development: New Paradigms?, FAC Working Paper 051, Brighton: Future Agricultures Consortium

Chang, H.J. (2011) 'How to "Do" a Developmental State: Political, Organisational and Human Resource Requirements for the Developmental State', in O. Edigheji (ed.), Constructing a Democratic Developmental State in South Africa: Potentials and Challenges, Cape Town: Human Sciences Research Council

Chichava, S.; Duran, J.; Cabral, L.; Shankland, A.; Buckley, L.; Lixia, T. and Yue, Z. (2013) Chinese and Brazilian Cooperation with African Agriculture: The Case of Mozambique, FAC Working Paper 049, Brighton: Future Agricultures Consortium

CONSEA, FAO and IICA (2009) Building up the National Policy and System for Food and Nutrition Security: The Brazilian Experience, Brasilia: CONSEA, FAO and IICA, www.fao.org.br/ download/Seguranca_Alimentar_Ingles.pdf (accessed 4 April 2013)

Costa Leite, I. (forthcoming) 'Solidarity, Interests and Professionalization in Brazilian Provision of International Cooperation: The More Food Africa Case', in C. Ayala and J. Rivera (eds), De la Diversidad a la Consonancia: La CSS Latinoamericada, Mexico DF: Instituto Mora

da Silva, J.G. (1981) A Modernização Dolorosa. Estrutura Agrária, Fronteira Agrícola e Trabalhadores Rurais no Brasil, Rio de Janeiro: Zahar Editores

Del Grossi, M.E. (2010) 'Assessment of Social Inclusion Policy in Rural Areas Transformations Through Family Allowance Policy and Public Policy for Family Farming', paper presented at the international conference on the Dynamics of Rural Transformations in Emerging Economies, New Delhi, 14-16 April

DIEESE (Departamento Intersindical de Estatística e Estudos Socioeconômicos), Núcleo de Estudos Agrários e Desenvolvimento Rural (NEAD) and
Ministério do Desenvolvimento Agrário (MDA) (2011) Estatísticas do Meio Rural 2010-2011, São Paulo: DIEESE, NEAD and MDA

Evans, P. (2011) 'Constructing the 21st Century Developmental State', in O. Edigheji (ed.), Constructing a Democratic Developmental State in South Africa: Potentials and Challenges, Cape Town: Human Sciences Research Council Gorender, J. (1994) 'Gênese e Desenvolvimento do Capitalismo no Campo Brasileiro', in J.P. Sedile (ed.), A Questão Agrária Hoje, Porto Alegre: Editora da Universidade/UFRGS Jayne, T.S.; Ballard Zulu; Nijhoff, J.J. and Tembo, G. (2005) 'Food Marketing and Prices Stabilization Policies in Eastern and Southern Africa: A Review of Experience and Lessons Learned', paper prepared for the workshop on Managing Food Price Instability and Risk in Low Income Countries, 28 February-1 March, Washington DC: World Bank

MDA (Ministério do Desenvoilvimento Agrário) (2009) Agricultura Familiar no Brasil e o Censo Agropecuário 2006, Brasília-DF

Moyo, S. (2011) 'The Agrarian Question and the Developmental State in Southern Africa', in O. Edigheji (ed.), Constructing a Democratic Developmental State in South Africa: Potentials and Challenges, Cape Town: Human Sciences Research Council

Moyo, S. and Yeros, P. (2005) Reclaiming the Land: The Resurgence of Rural Movements in Africa, Asia and Latin America, London and New York/Cape Town: Zed Books/David Philip

MRE (Ministério das Relações Exteriores) (2010) Diálogo Brasil-Africa sobre Segurança Alimentar, Combate à Fome e Desenvolvimento Rural: Adoção de Documento Final, www.itamaraty.gov.br/sala-deimprensa/notas-a-imprensa/dialogo-brasilafrica-sobre-seguranca-alimentar-combate-afome-e-desenvolvimento-rural-adocao-dedocumento-final (accessed 4 April 2013)

Neri, M.C. (coord.) (2010) A Nova Classe Média: O Lado Brilhante dos Pobres, Rio de Janeiro: FGV/CPS, www.cps.fgv.br/ibrecps/ncm2010/ NGM_Pesquisa_FORMATADA.pdf (accessed 4 April 2013)

Patriota, T. and Pierri, F. (2013) 'Brazil's Cooperation for Agriculture Development and Food Security in Africa: Assessing the Technology, Finance, and Knowledge Platforms', in F. Cheru and R. Modi (eds), Agricultural Development and Food Security in Africa: The Impact of Chinese, Indian and Brazilian Investments, London: Zed Books 
Souza, J.M. (1986) O Cativeiro da Terra, São Paulo: Editora Hucitec

UNAG (2012) Pronunciamento da UNAC Sobre o Programa ProSavana,União Nacional de Camponeses, www.unac.org.mz/index.php/7blog/39-pronunciamento-da-unac-sobre-oprograma-prosavana (accessed 15 November 2012)
Wanderley, M.N.B. (2011) Um Saber Necessário; os Estudos Rurais no Brasil, 1st edn, Campinas SP: Unicamp

Wiggins, S. (2009) Can the Smallholder Model Deliver Poverty Reduction and Food Security for a Rapidly Growing Population in Africa?, FAC Working Paper 08, Brighton: Future Agricultures Consortium 